\title{
Polyphasic Taxonomic Study of the Emended Genus Arcobacter with Arcobacter butzleri comb. nov. and Arcobacter skirrowii sp. nov., an Aerotolerant Bacterium Isolated from Veterinary Specimens
}

\author{
P. VANDAMME, ${ }^{1 *}$ M. VANCANNEYT,${ }^{1}$ B. POT,${ }^{1}$ L. MELS,${ }^{1}$ B. HOSTE,${ }^{1}$ D. DEWETTINCK, ${ }^{1}$ L. VLAES, ${ }^{2}$
} C. VAN DEN BORRE, ${ }^{2}$ R. HIGGINS,${ }^{3}$ J. HOMMEZ, ${ }^{4}$ K. KERSTERS, ${ }^{1}$ J.-P. BUTZLER, ${ }^{2}$ AND H. GOOSSENS ${ }^{2}$

Laboratorium voor Microbiologie, Ledeganckstraat 35, University of Ghent, B-9000 Ghent, Belgium ${ }^{1}$; World Health Collaborating Centre for Enteric Campylobacter, St. Pieters University Hospital, Brussels, Belgium ${ }^{2}$; Department of Pathology and Microbiology, Faculty of Veterinary Medicine, University of Montreal, Saint-Hyacinthe, Quebec, Canada ${ }^{3}$; and Provinciaal Verbond voor Dierenziektenbestrijding, Torhout, Belgium ${ }^{4}$

\begin{abstract}
The relationships of 77 aerotolerant Arcobacter strains that were originally identified as Campylobacter cryaerophila (now Arcobacter cryaerophilus [P. Vandamme, E. Falsen, R. Rossau, B. Hoste, P. Segers, R. Tytgat, and J. De Ley, Int. J. Syst. Bacteriol. 41:88-103, 1991]) and 6 reference strains belonging to the taxa Arcobacter nitrofigilis, Arcobacter cryaerophilus, and "Campylobacter butzleri" were studied by using a polyphasic approach, in which we performed DNA-rRNA hybridizations, DNA-DNA hybridizations, a numerical analysis of whole-cell protein patterns after sodium dodecyl sulfate-polyacrylamide gel electrophoresis, an analysis of cellular fatty acid compositions, and a phenotypic analysis and determined DNA base ratios. Our results indicate that " $C$. butzleri" should be transferred to the genus Arcobacter as Arcobacter butzleri comb. nov., as was suggested by Kiehlbauch and coworkers (J. A. Kiehlbauch, D. J. Brenner, M. A. Nicholson, C. N. Baker, C. M. Patton, A. G. Steigerwalt, and I. K. Wachsmuth, J. Clin. Microbiol. 29:376-385, 1991). A rapid screening of all strains in which we used the sodium dodecyl sulfate-polyacrylamide gel electrophoresis technique revealed five major groups, which were identified by using DNA-DNA hybridization data as $A$. cryaerophilus (two distinct electrophoretic subgroups), $A$. butzleri, $A$. nitrofigilis, and a new species, for which we propose the name Arcobacter skirrowii. The phylogenetic position within rRNA superfamily VI was established for each species. $A$. butzleri strains and strains belonging to one of the electrophoretic subgroups of $A$. cryaerophilus had similar fatty acid contents. An analysis of fatty acid compositions allowed clear-cut differentiation of all of the other groups. All of the species could be distinguished by using classical phenotypic tests, although erroneous identifications due to a shortage of clear-cut differentiating tests could occur.
\end{abstract}

In the late $1970 \mathrm{~s}$, Ellis and coworkers described spiralshaped bacteria which were isolated from aborted bovine and porcine fetuses $(5,6)$. These strains were identified as campylobacters (23) and constituted two distinct biochemical groups; the so-called group 1 strains were identified as Campylobacter fetus, and the group 2 strains belonged to a previously undescribed Campylobacter taxon (22). Other investigators isolated bacteria that were similar to the group 2 strains from aborted porcine and bovine fetuses $(10,11)$, from the milk of cows with mastitis (17), and from a bovine preputial sheath washing (7). All of these organisms differed from the true campylobacters by their ability to grow in the presence of atmospheric oxygen after primary isolation in a microaerobic environment (22). Therefore, they were referred to as the aerotolerant campylobacters. The biochemical and physiological properties of 90 aerotolerant Campylobacter strains were examined by Neill et al. (21). Although these authors found a considerable degree of phenotypic heterogeneity, they proposed a single name, Campylobacter cryaerophila, for the organisms which were isolated from reproductive tracts and aborted fetuses of several species of farm animals, from animal feces, and from the milk of cows with mastitis (21). The pathogenicity of $C$. cryaerophila was

\footnotetext{
* Corresponding author.
}

unknown. A few years later, Lambert et al. (16) and Tee et al. (28) described the isolation of $C$. cryaerophila-like strains from human clinical sources. Preliminary DNA-DNA hybridization results of Vandamme et al. (32) showed that three atypical $C$. cryaerophila strains exhibited no significant DNA binding values with genuine $C$. cryaerophila strains. Kiehlbauch et al. (12) performed an extensive DNA-DNA hybridization study and phenotypic analysis of 78 aerotolerant Campylobacter strains and identified two DNA relatedness groups. Some of the strains which these authors studied belonged to $C$. cryaerophila, but most of their strains were members of a separate species that exhibited a level of DNA homology with $C$. cryaerophila of approximately $40 \%$. The name "Campylobacter butzleri" was proposed by Kiehlbauch et al. (12) (as this name was not validly published, it is enclosed in quotation marks). Within the true species $C$. cryaerophila, two genotypic and phenotypic subgroups were identified (12). The phenotypic features which were used did not allow clear-cut differentiation between one of these subgroups (corresponding to DNA hybridization group 1B) and "C. butzleri" (12). The same authors showed that the three DNA homology groups ("C. butzleri," C. cryaerophila hybridization group $1 \mathrm{~A}$, and $C$. cryaerophila hybridization group 1B) could be differentiated by the presence of specific ribosomal DNA restriction fragments (13).

The phylogenetic relationships of the aerotolerant cam- 
pylobacters have been determined by using the DNA-rRNA hybridization technique (32) and comparative 16S rRNA sequencing (29). C. cryaerophila and Campylobacter nitrofigilis are members of a separate rRNA homology branch that deserves separate genus status $(29,32)$. The genus name Arcobacter has been proposed for this group, with Arcobacter nitrofigilis as the type species and Arcobacter cryaerophilus as an additional species. In an addendum in proof, Kiehlbauch et al. (12) concluded from their results that " $C$. butzleri" also belongs to the genus Arcobacter as it exhibits a level of DNA homology with $C$. cryaerophila (12) (now $A$. cryaerophilus [32]) of approximately $40 \%$; the name of this organism should be Arcobacter butzleri. Below, we formally transfer " $C$. butzleri" to the genus Arcobacter as $A$. butzleri comb. nov. This name and the name Arcobacter skirrowii, which we propose for a new species of aerotolerant arcobacters, are used below.

In this study we used a polyphasic approach to determine the taxonomic structure and the phylogenetic relationships of 77 strains that were originally identified as $C$. cryaerophila.

\section{MATERIALS AND METHODS}

Isolation of Arcobacter strains. Of the 83 strains which we studied, 45 were our own isolates. Arcobacter strains are seldom isolated by using the routine culture methods used for campylobacters and Campylobacter-like bacteria. The first Arcobacter strains were isolated by Ellis et al. $(5,6)$, who used a semisolid Leptospira medium. A distinct growth zone below the surface was observed if arcobacters were present. Adding $100 \mu \mathrm{g}$ of 5-fluorouracil per $\mathrm{ml}$ to the growth medium inhibited the contaminating flora but did not influence the growth of Arcobacter strains $(6,10)$. Neill et al. (24) described a two-stage isolation method. First, samples were inoculated into the semisolid medium described above. After growth was visible, a few drops from the growth zone below the surface was streaked onto blood agar base containing 125 $\mu \mathrm{g}$ of carbenicillin per $\mathrm{ml}$. Other investigators have used direct filtration techniques (7).

In our study, strains LMG 9800 through LMG 9803 and LMG 11072 through LMG 11078 (all identified as $A$. skirrowii [see below]) were isolated from preputial fluids of bulls. The fluid was inoculated into a transport medium. The inoculated transport medium was taken to our laboratory and centrifuged. Then the supernatant was filtered through a membrane filter (pore size, $0.8 \mu \mathrm{m}$; Millex). The first drops were discarded, and then 5 or 6 drops were streaked onto the following media: (i) thioglycolate agar (catalog no. 0257-01-9; Difco Laboratories, Detroit, Mich.) supplemented with $10 \%$ sheep blood, $25 \mathrm{IU}$ of bacitracin per $\mathrm{ml}, 5 \mathrm{IU}$ of polymyxin B sulfate per $\mathrm{ml}, 0.005 \mathrm{mg}$ of novobiocin per $\mathrm{ml}$, and $0.05 \mathrm{mg}$ of cycloheximide (Acti-Dione) per ml; (ii) the same medium without polymyxin B sulfate; (iii) tryptone soya agar (catalog no. CM131; Oxoid, Ltd., Basingstoke, United Kingdom) containing the Brucella selective supplement (catalog no. SR83; Oxoid); and (iv) MacConkey agar (catalog no. CM7; Oxoid). Positive cultures were obtained in the thioglycolate medium without polymyxin B sulfate. Two strains were also isolated from the same medium containing polymyxin $B$ sulfate. No positive cultures were found on the other media. Grey, flat, watery colonies were visible after 3 to 4 days of incubation in a microaerobic atmosphere at $37^{\circ} \mathrm{C}$.

Strains LMG 10209 through LMG 10244 were isolated mainly from the tissues of fetuses when we were searching for leptospires. The medium used was semisolid PLM-5 medium (catalog no. 0242-00; Armour Pharmaceutical Co., Kankakee, Ill.) supplemented with $200 \mu \mathrm{g}$ of 5-fluorouracil per ml. The tubes were checked by using dark-field examination; when Campylobacter-like organisms were observed, subculturing was carried out on nutrient agar no. 2 (catalog no. CM67; Oxoid).

Bacterial strains and growth conditions. All of the strains which we used are listed in Table 1 . We received the type strain of $A$. butzleri (strain LMG 10828) and the reference strain of $A$. cryaerophilus hybridization group 1B (strain LMG 10829) from J. Kiehlbauch, Centers for Disease Control, Atlanta, Ga. Two reference strains of $A$. nitrofigilis (strains LMG 7604 ${ }^{\mathrm{T}}$ [T = type strain] and LMG 7547) and the type strain of $A$. cryaerophilus (strain LMG 7536) were sent by $E$. Falsen from the Culture Collection of the University of Göteborg, Göteborg, Sweden. A second subculture of the type strain of $A$. cryaerophila (strain LMG 9904) was sent by S. D. Neill from the Veterinary Research Laboratories, Belfast, Northern Ireland.

Most aerotolerant strains (except the strains that were identified as $A$. butzleri) grew weakly on the common blood agar bases, including $5 \%$ (vol/vol) horse blood in MuellerHinton agar (catalog no. CM337; Oxoid), nutrient agar no. 2 (catalog no. CM67; Oxoid), Columbia agar (catalog no. CM331; Oxoid), and brain heart infusion agar (catalog no. CM375; Oxoid). Growth was not markedly enhanced on chocolate agar plates. We obtained good growth on a medium that contained (per liter) $10 \mathrm{~g}$ of Special Peptone (catalog no. L72; Oxoid), $5 \mathrm{~g}$ of Lab Lemco powder (catalog no. L29; Oxoid), $5 \mathrm{~g}$ of yeast extract (catalog no. L21; Oxoid), $5 \mathrm{~g}$ of sodium chloride (catalog no. 6404; Merck, Darmstadt, Germany), $2 \mathrm{~g}$ of sodium succinate hexahydrate (catalog no. RPL 1785; RPL, Leuven, Belgium), $2 \mathrm{~g}$ of sodium L-glutamate monohydrate (catalog no. 6445; Merck), $1 \mathrm{~g}$ of magnesium chloride hexahydrate (catalog no. 5833; Merck), and $16 \mathrm{~g}$ of agar no. 3 (catalog no. L13; Oxoid); the final $\mathrm{pH}$ was 7.0 . We refer to this growth medium below as the standard medium. This standard medium was supplemented with $5 \%(\mathrm{vol} / \mathrm{vol})$ horse blood or with $0.4 \%$ (wt/vol) bacteriological charcoal (catalog no. L9; Oxoid), and the supplemented media supported similar growth. If the media were stored for more than 1 week, the charcoal-based medium gave better growth results than the blood agar. $A$. nitrofigilis strains were cultured on nutrient agar no. 2 (catalog no. CM67; Oxoid) supplemented with $1 \%$ sodium chloride (catalog no. 6404; Merck).

All of the strains were incubated at 36 to $37^{\circ} \mathrm{C}$ in a microaerobic atmosphere containing $5 \% \mathrm{O}_{2}, 10 \% \mathrm{CO}_{2}$, and $85 \% \mathrm{~N}_{2}$ unless indicated otherwise. Including $7.5 \%$ hydrogen in the microaerobic atmosphere (containing approximately $5 \% \mathrm{O}_{2}, 3.5 \% \mathrm{CO}_{2}, 7.5 \% \mathrm{H}_{2}$, and $84 \% \mathrm{~N}_{2}$ ) enhanced the growth of only a few strains.

Bacteriological purity was checked by plating and examining living and Gram-stained cells. For mass cultures, cells were grown on approximately 20 petri dishes (diameter, 9 $\mathrm{cm})$.

PAGE of whole-cell proteins. The cell yields of three or four petri dishes were required to obtain the amount of wet cell weight needed for polyacrylamide gel electrophoresis (PAGE) (approximately $70 \mathrm{mg}$ ), and we used Mueller-Hinton agar (catalog no. CM337; Oxoid) supplemented with 5\% horse blood as the growth medium. A data base for the identification of campylobacters and related organisms (such as Arcobacter and Helicobacter strains) by means of a numerical analysis of whole-cell protein profiles has been accumulated, and the same growth medium and incubation 

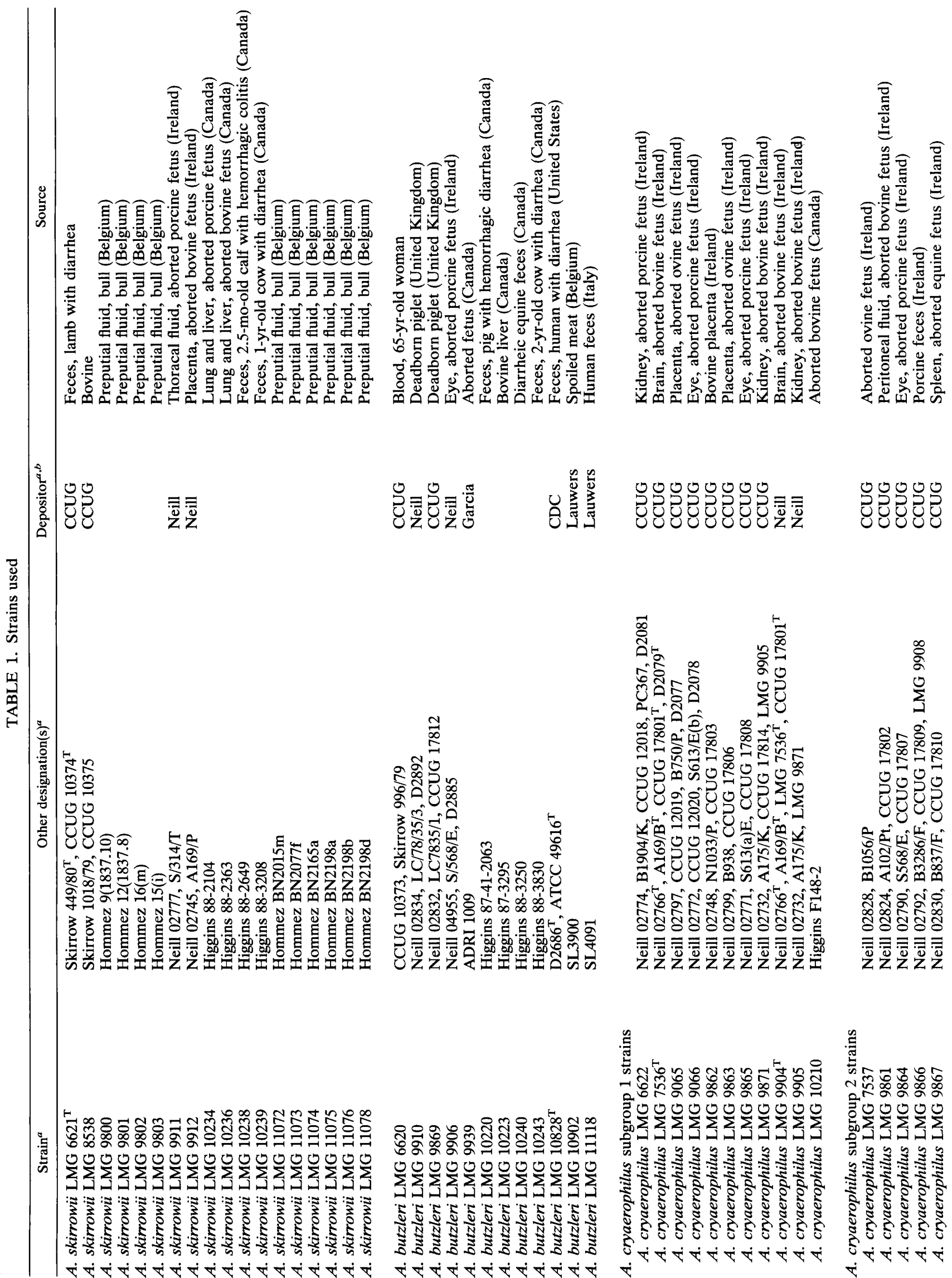

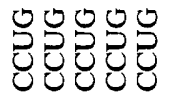
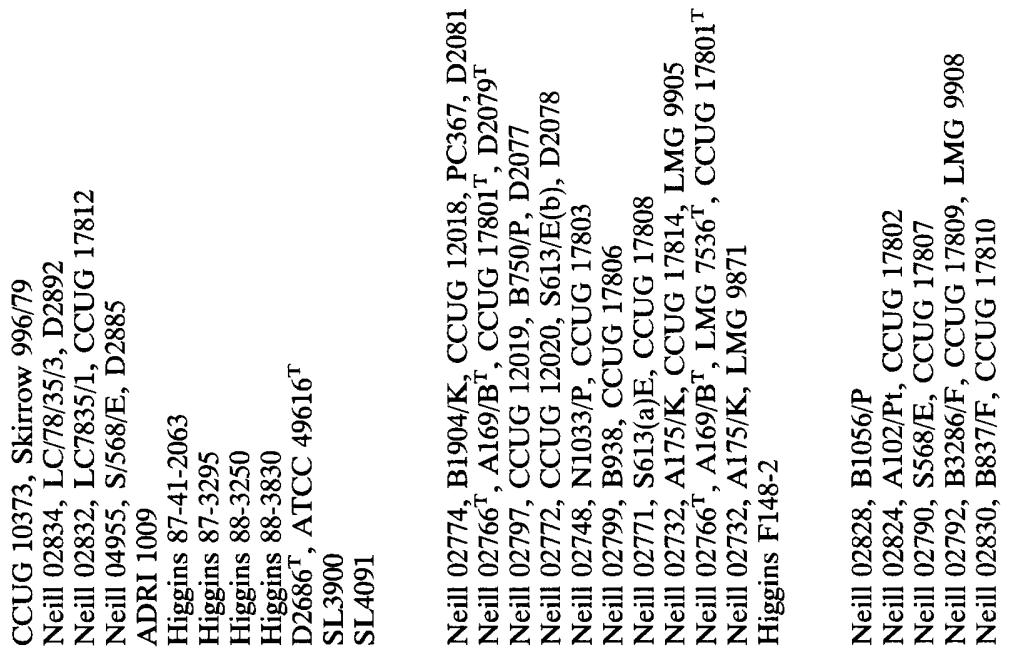

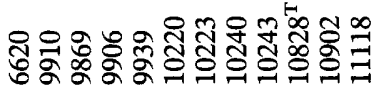

胥

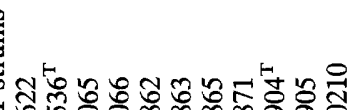

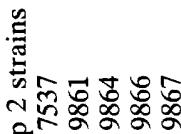

눙의

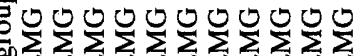

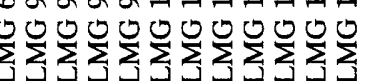

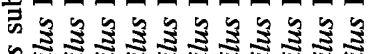

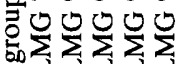

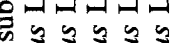

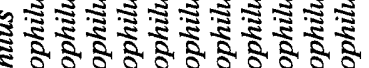

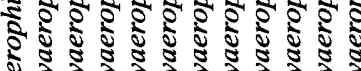
马 3 2.252 복ำ

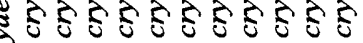

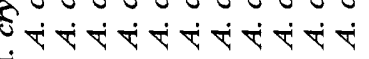
2. 2 कर

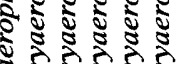

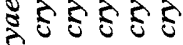
हंसं सं

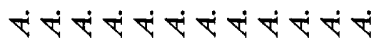




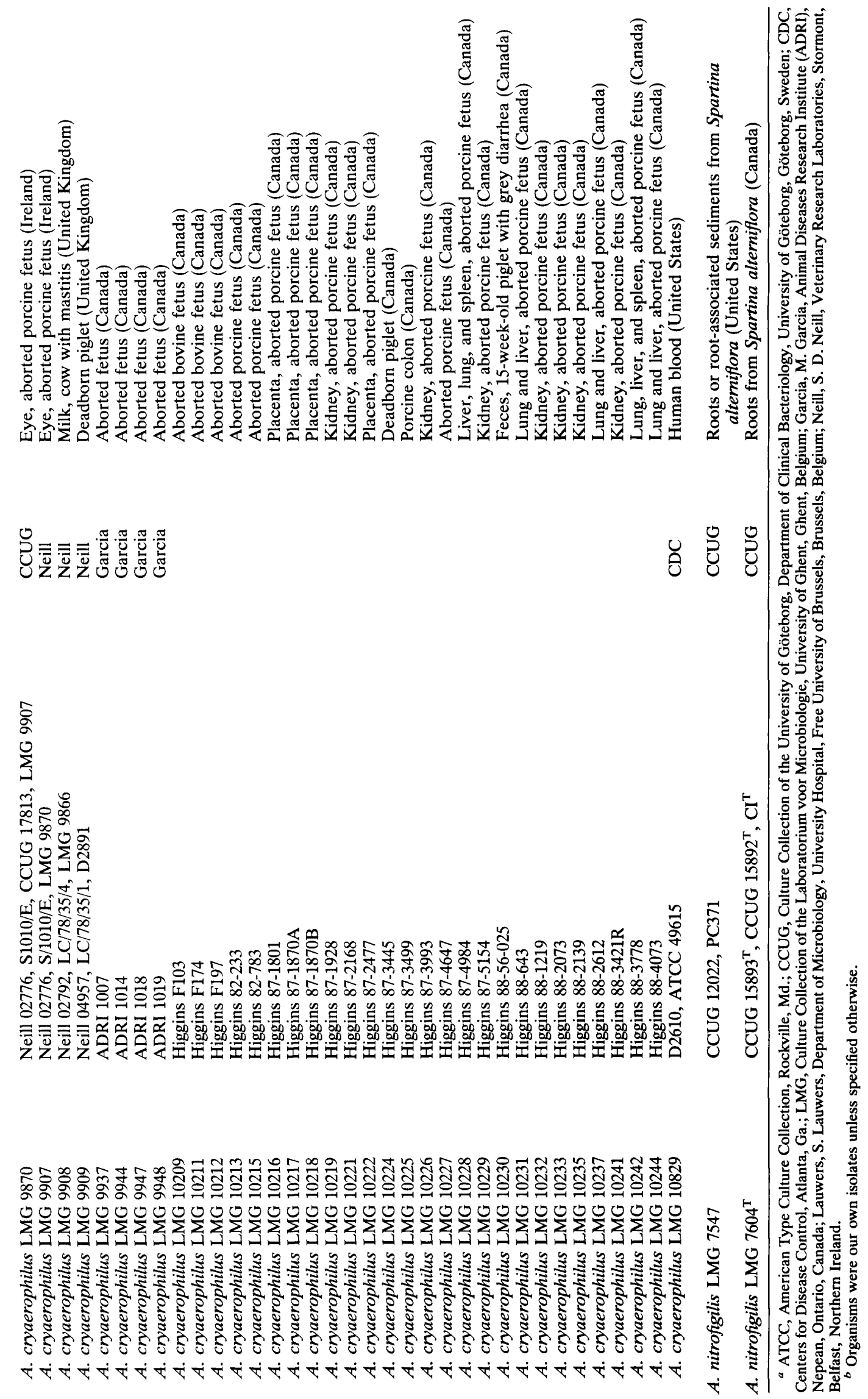


conditions were used for nearly all of the strains (35). For this reason, all of the strains were incubated in a microaerobic atmosphere containing approximately $5 \% \mathrm{O}_{2}, 3.5 \%$ $\mathrm{CO}_{2}, 7.5 \% \mathrm{H}_{2}$, and $84 \% \mathrm{~N}_{2}$. Whole-cell protein extracts were prepared, and sodium dodecyl sulfate (SDS)-PAGE was performed by using the procedure of Laemmli (15), modified slightly as described previously (31).

Numerical analysis of protein gel electropherograms. The densitometric analysis, normalization, and interpolation of the protein profiles were performed as described by Pot et al. (25). A numerical analysis was performed as described by Vauterin et al. (36) on points 10 to 120 and points 150 to 310 of the 400 points of each interpolated trace. The profiles were recorded and stored on a PC-AT computer. The levels of similarity between all pairs of traces were expressed by using the Pearson product moment correlation coefficient $(r)$, and clustering was performed by using the unweighed pair group method using average linkage (26).

Preparation of high-molecular-weight DNA. High-molecular-weight native DNA was prepared from 1.5 to $3 \mathrm{~g}$ (wet weight) of cells. Bacterial cells were harvested and washed in saline-EDTA buffer $(0.15 \mathrm{M} \mathrm{NaCl}$ plus $0.1 \mathrm{M}$ EDTA, $\mathrm{pH}$ 8). A 1-g portion of cells was suspended in approximately 30 $\mathrm{ml}$ of buffer. Proteinase K (catalog no. 24568; Merck) $(0.625$ $\mathrm{mg} / \mathrm{g}$ [wet weight] of cells) and $1.5 \mathrm{ml}$ of $25 \%$ SDS were added. The resulting solution was incubated for 15 to $30 \mathrm{~min}$ at $37^{\circ} \mathrm{C}$. The total $\mathrm{NaCl}$ concentration was adjusted to $1 \mathrm{M}$, and the DNA solution was vigorously shaken for a few seconds. The DNA emulsion was then gently shaken for 30 min at room temperature and centrifuged, and the supernatant was removed. The DNA was precipitated by adding 2 volumes of ethanol, spooled on a glass rod, and dissolved at $45^{\circ} \mathrm{C}$ in $0.1 \times \mathrm{SSC}(1 \times \mathrm{SSC}$ is $0.15 \mathrm{M} \mathrm{NaCl}$ plus $0.015 \mathrm{M}$ sodium citrate, $\mathrm{pH} 7$ ). Then $1.25 \mathrm{ml}$ of a $0.2 \%$ solution of RNase (catalog no. 34390; Serva Feinbiochemica GMBH \& Co., Heidelberg, Germany) per g (wet weight) was added, and the mixture was incubated for $30 \mathrm{~min}$ at $45^{\circ} \mathrm{C}$. The deproteinization step described above was repeated, and the DNA was finally suspended in 1 to $3 \mathrm{ml}$ of $0.1 \times$ SSC and stored at $-80^{\circ} \mathrm{C}$.

DNA-DNA hybridization experiments. The degree of DNADNA binding, expressed as a percentage, was determined spectrophotometrically by using the initial renaturation rate method of De Ley et al. (3). Each value given below is the average of values from at least two hybridization experiments. DNA binding values of $30 \%$ and less do not indicate significant DNA homology. The total DNA concentration was about $39 \mu \mathrm{g} / \mathrm{ml}$, and the optimal renaturation temperature in $2 \times \mathrm{SSC}$ was $61.6^{\circ} \mathrm{C}$.

DNA base compositions. All of the guanine-plus-cytosine $(G+C)$ values were determined by the thermal denaturation method and were calculated by using the equation of Marmur and Doty (18), as modified by De Ley (2).

DNA-rRNA hybridization experiments. In vivo radioactively labeled rRNAs from $A$. nitrofigilis LMG 7547 and $A$. butzleri LMG 6620 were prepared as described previously (32). Fixation of single-stranded DNA on membrane filters, chemical determinations of the amounts of DNAs on the filters, saturation hybridization, RNase treatment, and thermostability measurements of hybrids were performed as described by De Ley and De Smedt (4). Each DNA-rRNA hybrid was characterized by determining the $T_{m(e)}$ value (the melting temperature of elution), the temperature at which $50 \%$ of the DNA-rRNA hybrid was denatured. A homologous duplex was formed between DNA and rRNA from the same strain; a heterologous hybrid was formed between
DNA and rRNA from different strains. The higher the $T_{m(e)}$ of a heterologous hybrid, the more closely the two strains were related. The $T_{m(e)}$ values obtained from reciprocal hybridizations in which we used all of the strains of each rRNA branch were used to calculate the average linkage levels between pairs of rRNA branches.

Gas chromatographic analysis of FAMEs. To prepare fatty acid methyl esters (FAMEs), one or two petri dishes (diameter, $9 \mathrm{~cm}$ ) containing the standard medium supplemented with $5 \%$ horse blood were inoculated for each strain. The cultures were incubated for $72 \mathrm{~h}$ at $37^{\circ} \mathrm{C}$ in a microaerobic atmosphere containing approximately $5 \% \mathrm{O}_{2}, 3.5 \% \mathrm{CO}_{2}$, $7.5 \% \mathrm{H}_{2}$, and $84 \% \mathrm{~N}_{2}$. A loopful of well-grown cells of each strain was harvested with a sterile plastic loop (diameter, 4 $\mathrm{mm}$ ) and transferred to a test tube capped with a Teflon-lined screw cap. To prepare FAMEs, the procedure described by Stead (27) was used. FAMEs were separated by gas-liquid chromatography by using a model $5890 \mathrm{~A}$ instrument (Hewlett-Packard Co., Avondale, Pa.) and fused silica capillary column ( $25 \mathrm{~m}$ by $0.2 \mathrm{~mm}$ ) that was coated with methyl phenyl silicone (Hewlett-Packard). The computer-controlled parameters for the instrument were the same as those described by Korn-Wendisch et al. (14). FAME fingerprints were identified by using the Microbial Identification System software package (MIS version no. 3.2) obtained from Microbial ID, Inc., Newark, Del., and a calibration mixture of known standards (Hewlett-Packard). FAME profiles were compared and grouped by using principal-component analysis. Within each individual FAME group, the fatty acid mean percentages and standard deviations were calculated.

Phenotypic tests. Phenotypic tests were performed on all Arcobacter strains. The morphology of cells was evaluated by Gram staining. Motility was observed in young cultures by examining wet mounts in broth by phase-contrast microscopy. The following tests were performed as described previously (9): temperature tolerance; growth under aerobic and anaerobic conditions; presence of oxidase and catalase; reduction of nitrate and nitrite; hydrogen sulfide production in triple sugar iron agar and as determined with the rapid $\mathrm{H}_{2} \mathrm{~S}$ test; oxidation and fermentation of carbohydrates; hydrolysis of hippurate, DNA, urea, and indoxyl acetate; susceptibility to nalidixic acid and cephalothin ( $30-\mu \mathrm{g}$ discs); and growth in the presence of $1 \%$ glycine, $1 \%$ oxgall, 1.5 and $3.5 \% \mathrm{NaCl}$, and $0.04 \%$ 2,3,5-triphenyltetrazolium chloride (TTC). Tests for growth in the presence of $8 \%$ glucose, growth in MacConkey agar, and hydrogen sulfide production from cysteine were performed as described by Barrett et al. (1). The test for growth on VB medium consisted of growing the organisms on the previously described selective medium at $37^{\circ} \mathrm{C}$ in a microaerobic atmosphere (8).

\section{RESULTS}

PAGE of whole-cell proteins. We prepared duplicate protein extracts of several strains to check the reproducibility of the growth conditions and the preparation of the extracts. The level of correlation $(r)$ between duplicate protein patterns was $\geq 0.95$.

For four strains we received two subcultures that originated from different depositors (Table 1). The two subcultures of each pair (except the subcultures of the type strain of $A$. cryaerophilus) produced identical protein profiles; these subcultures grouped in the numerical analysis at $r$ levels of $\geq 0.95$ (Fig. 1). Minor differences between the protein patterns of the two subcultures of the type strain of 


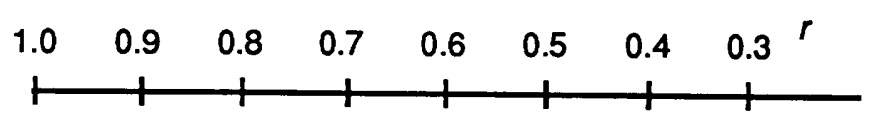

\section{Arcobacter cryaerophilus subgroup 1}

\section{Arcobacter cryaerophilus subgroup 2}

\section{Arcobacter skirrowii}

\section{Arcobacter butzleri}

\section{Arcobacter nitrofigilis}

LMG 9871 LMG 9905 LMG 7536T LMG 9863

LMG 9904T

LMG 9065

LMG 9865

LMG 6622

LMG 9862

LMG10225

LMG10224

LMG10232

LMG10230

LMG 9861

LMG10241

LMG10222

LMG10221

LMG 9907

LMG 9870

LMG10235

LMG10215

LMG 9937

LMG10216

LMG 9944

LMG 7537

LMG10231

LMG10829

LMG10228

LMG10218

LMG10217

LMG10213

LMG10226

LMG10233

LMG10209

LMG 9867

LMG 9909

LMG 9864

LMG10244

LMG10237

LMG10212

LMG10211

LMG10229

LMG 9908

LMG 9866

LMG 9866

LMG10234

LMG 11075

LMG 11073

LMG 9802

LMG10239

LMG 6621T

LMG 9801

LMG10236

LMG 9800

LMG 9803

LMG 11072

LMG 8538

LMG 9911

LMG 11074

LMG 11078

LMG 11076

LMG10238

LMG 9939

LMG10220

LMG10223

LMG10240

LMG 9906

LMG 9910

LMG 9869

LMG 6620

LMG 11118

LMG10828T

LMG10243

LMG10902

LMG 9947

LMG10219

LMG 9948

LMG 7547

LMG 7604T

LMG10227

LMG10210

LMG10242

LMG 9066

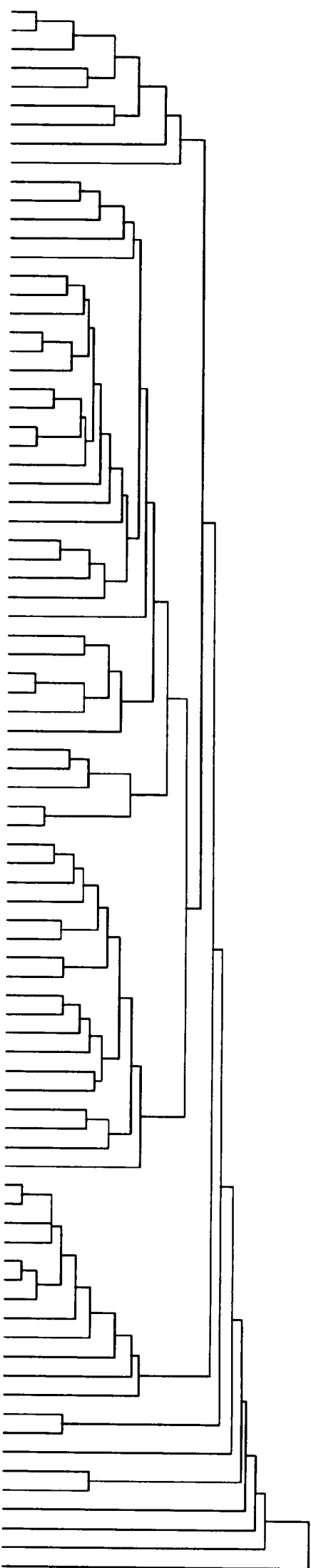

FIG. 1. Dendrogram derived from unweighed pair group average linkage of $r$ values for the reduced protein patterns (points 10 through 120 and 150 through 310 ) of all of the strains studied. The roman numerals are cluster numbers. 


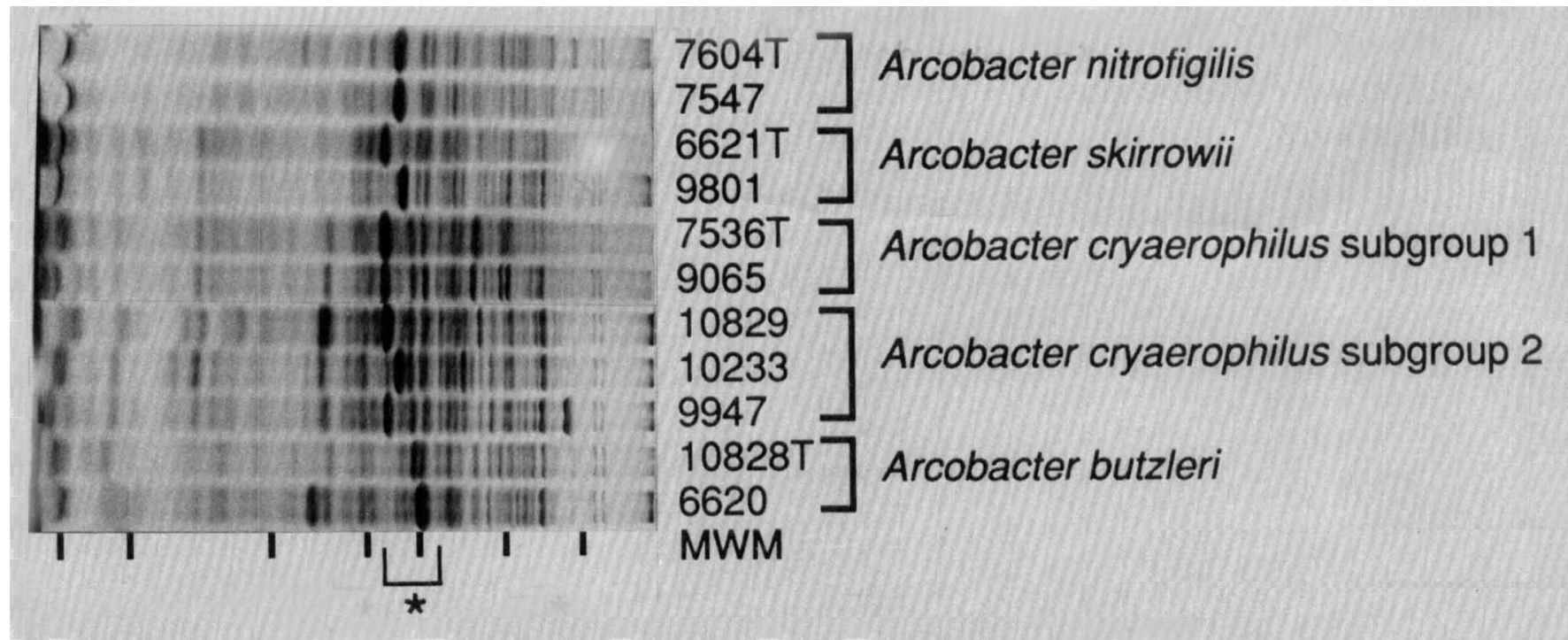

FIG. 2. Electrophoretic protein profiles of representative strains belonging to each electrophoretic cluster and a strain that occupied a separate position on the dendrogram (strain LMG 9947). All strain designations are LMG numbers (see Table 1, footnote $a$ ). The positions of the following molecular weight markers (track MWM) are indicated (from left to right): lysozyme (molecular weight, 14,500), trypsin inhibitor $(20,100)$, carbonic anhydrase $(29,000)$, glyceraldehyde-3-phosphate dehydrogenase $(36,000)$, egg albumin $(45,000)$, bovine albumin $(66,000)$, and $\beta$-galactosidase $(116,000)$. The bracket marked with an asterisk indicates a variable dense-band region that was omitted from the numerical analysis.

A. cryaerophilus (strains LMG 7536 and LMG 9904) were found; the $r$ level for these two profiles was 0.87 (Fig. 1).

Our numerical analysis of the complete protein patterns (points 10 to 310 ) was distorted by the presence of a variable dense-band region similar to the principal dense-band region previously described for Campylobacter strains (35). This region was situated in the 40,000 - to 58,000 -molecular-weight range (points 121 to 149 of the profile) (Fig. 2). Therefore, these points were omitted from the numerical analysis, which resulted in clear-cut grouping of nearly all of the strains studied. It has been shown previously that the clusters obtained in such a restricted analysis are also genotypically homogeneous $(34,35)$.

Above an $r$ level of 0.77 , five major clusters and seven strains having separate positions were delineated (Fig. 1). Cluster I contained the two subcultures of the type strain of $A$. cryaerophilus and seven aerotolerant strains; these or- ganisms grouped at an $r$ level of more than 0.78 . We refer to these strains below as the $A$. cryaerophilus subgroup 1 strains. Cluster II consisted of 35 aerotolerant Arcobacter strains, including the reference strain of $A$. cryaerophilus hybridization group 1B (strain LMG 10829) (12), which grouped at an $r$ level of more than 0.78 ; below, we refer to these strains as the $A$. cryaerophilus subgroup 2 strains. Cluster III contained 18 aerotolerant isolates that grouped at an $r$ level of more than 0.83 ; below, we show that these strains are members of a new Arcobacter species, for which we propose the name Arcobacter skirrowii. Cluster IV $(r>$ 0.84 ) contained $A$. butzleri LMG $10828^{\mathrm{T}}$ ( $\mathrm{T}=$ type strain) and 11 aerotolerant isolates which were identified as $A$. butzleri strains. The two $A$. nitrofigilis strains constituted cluster V at an $r$ level of 0.88 . Strains LMG 9066, LMG 9947, LMG 9948, LMG 10210, LMG 10219, LMG 10227, and LMG 10242 had separate positions at an $r$ level of 0.77 . Strains

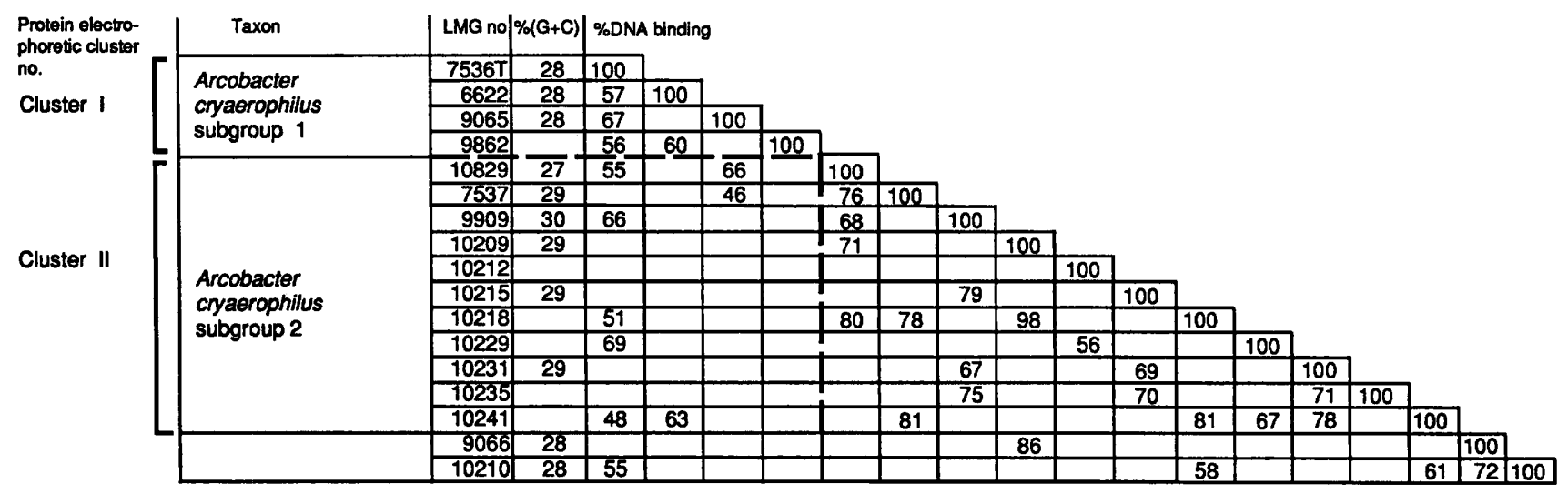

FIG. 3. DNA-DNA hybridization results and DNA base compositions of $A$. cryaerophilus strains. Each DNA-DNA hybridization value is the average degree of binding from at least two hybridization experiments. LMG, Culture Collection of the Laboratorium voor Microbiologie, University of Ghent, Ghent, Belgium. 


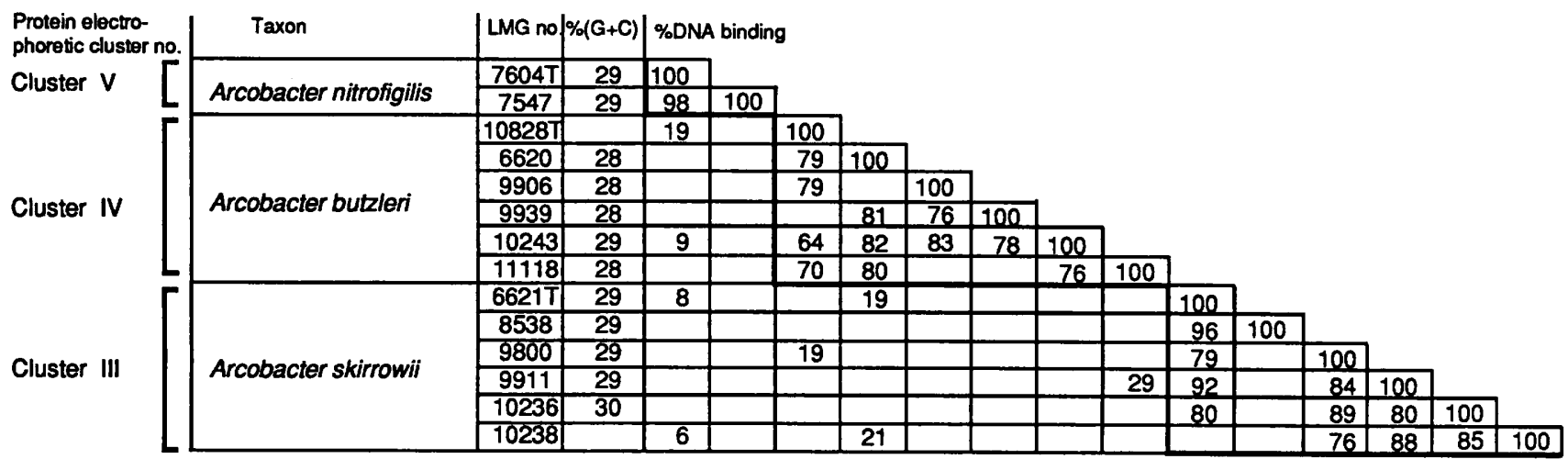

FIG. 4. DNA-DNA hybridization results and DNA base compositions of $A$. nitrofigilis, $A$. butzleri and $A$. skirrowii strains. Each DNA-DNA hybridization value is the average degree of binding from at least two hybridization experiments. LMG, Culture Collection of the Laboratorium voor Microbiologie, University of Ghent, Ghent, Belgium.

LMG 9947 and LMG 10219 grouped at an $r$ level of 0.94 (Fig. 1). The overall protein profiles of strains LMG 9066 and LMG 10210 were very similar to the profiles of the cluster I strains, while the protein profiles of strains LMG 9947, LMG 9948, LMG 10219, LMG 10227, and LMG 10242 corresponded to the profiles of the cluster II strains (this is illustrated for strain LMG 9947 in Fig. 2). These strains had an atypical dense protein band in the high-molecular-weight region (molecular weight, approximately 100,000) which disturbed the result of the numerical analysis. Nevertheless, these strains were closely related to the strains in their respective clusters (34). Similar protein bands have been described previously for $A$. cryaerophilus, Campylobacter sputorum and Campylobacter fetus $(34,35)$, and Campylobacter concisus strains (33).

The protein patterns of representative strains belonging to clusters I through $\mathrm{V}$ are shown in Fig. 2.

DNA-DNA hybridization results. We chose a number of representative strains from each electrophoretic cluster to perform DNA-DNA hybridizations; we used 4 strains from cluster I (A. cryaerophilus subgroup 1), 11 strains from cluster II (A. cryaerophilus subgroup 2), 6 strains from cluster III (A. skirrowii) and cluster IV (A. butzleri), and two strains from cluster $\mathrm{V}(A$. nitrofigilis $)$. The type strain of each taxon was included. We also prepared DNAs from two strains that had separate positions on the dendrogram (strains LMG 9066 and LMG 10210) and could be allocated visually to $A$. cryaerophilus subgroup 1 (see above) (Fig. 2).

The hybridization results revealed that there were four DNA homology groups (Fig. 3 and 4). The A. cryaerophilus subgroup 1 and 2 strains (clusters I and II, respectively) were related at the species level (the DNA binding values ranged from 46 to $69 \%$ ) (Fig. 3); within these groups, DNA binding values of more than $56 \%$ were found (Fig. 3). Strains of $A$. cryaerophilus exhibited no significant DNA binding with strains of the other Arcobacter species (data not shown). The DNA binding values versus $A$. skirrowii, $A$. butzleri, and $A$. nitrofigilis strains (clusters III, IV, and V, respectively) were $32 \pm 10,21 \pm 6$, and $16 \pm 1 \%$ (means \pm standard deviations of 12,6 , and 2 binding values, respectively). Within $A$. skirrowii, $A$. butzleri, and $A$. nitrofigilis, DNA binding values greater than 76,64 , and $98 \%$, respectively, were found (Fig. 4). Strains of these Arcobacter species exhibited no significant DNA binding values $(<30 \%)$ with strains belonging to other Arcobacter species (Fig. 4).

DNA base compositions. The DNA base ratios which we determined are shown in Fig. 3 and 4. All of the Arcobacter strains had $\mathrm{G}+\mathrm{C}$ contents between 27 and $30 \mathrm{~mol} \%$ (Fig. 3 and 4).

DNA-rRNA hybridizations. The DNA-rRNA hybridization results are shown in Table 2 and are represented as a dendrogram based on the $T_{m(e)}$ values of the hybrids in Fig. 5. Some of these results have been published previously (32). As shown previously, Arcobacter strains belong to rRNA superfamily VI, a separate eubacterial lineage within the class Proteobacteria (30). A. nitrofigilis and $A$. butzleri strains constitute separate rRNA branches that are linked at a $T_{m(e)}$ of $72.4 \pm 1.3^{\circ} \mathrm{C}$. $A$. cryaerophilus and $A$. skirrowii strains had similar $T_{m(e)}$ values versus both labeled rRNAs (averages \pm standard deviations, $71.6 \pm 1.0$ and $71.5 \pm$ $0.9^{\circ} \mathrm{C}$, respectively).

FAME composition. The average FAME composition of the strains of each Arcobacter taxon is shown in Table 3. Values for those fatty acids for which the average amount was less than $1 \%$ for all strains of the taxon (18:0 and unidentified fatty acids with equivalent chain lengths of

TABLE 2. $T_{m(e)}$ values of DNA-rRNA hybrids

\begin{tabular}{|c|c|c|}
\hline \multirow{2}{*}{$\begin{array}{l}\text { Organism used for } \\
\text { DNA isolation }\end{array}$} & \multicolumn{2}{|c|}{$\begin{array}{c}T_{m(e)}\left({ }^{\circ} \mathrm{C}\right) \text { when hybridized } \\
\text { with rRNA from: }\end{array}$} \\
\hline & $\begin{array}{l}\text { A. nitrofigilis } \\
\text { LMG } 7547\end{array}$ & $\begin{array}{l}\text { A. butzleri } \\
\text { LMG } 6620\end{array}$ \\
\hline A. nitrofigilis LMG $7604^{\mathrm{T}}$ & 76.3 & 72.7 \\
\hline A. nitrofigilis LMG 7547 & 76.7 & 73.3 \\
\hline A. butzleri LMG 6620 & 73.8 & 76.8 \\
\hline A. butzleri LMG $10828^{\mathrm{T}}$ & 70.1 & 75.6 \\
\hline A. butzleri LMG 11118 & 72.6 & 75.7 \\
\hline A. skirrowii LMG $6621^{\mathrm{T}}$ & 70.1 & 71.9 \\
\hline A. skirrowii LMG 8538 & 72.4 & 71.4 \\
\hline \multicolumn{3}{|l|}{ A. cryaerophilus subgroup 1 strains } \\
\hline A. cryaerophilus LMG $7536^{\mathrm{T}}$ & 71.8 & 72.6 \\
\hline A. cryaerophilus LMG 6622 & 72.3 & 71.8 \\
\hline A. cryaerophilus LMG 9065 & 71.9 & 70.6 \\
\hline \multicolumn{3}{|l|}{ A. cryaerophilus subgroup 2 strains } \\
\hline A. cryaerophilus LMG 7537 & 72.5 & 72.4 \\
\hline A. cryaerophilus LMG 10241 & 70.0 & 70.0 \\
\hline
\end{tabular}



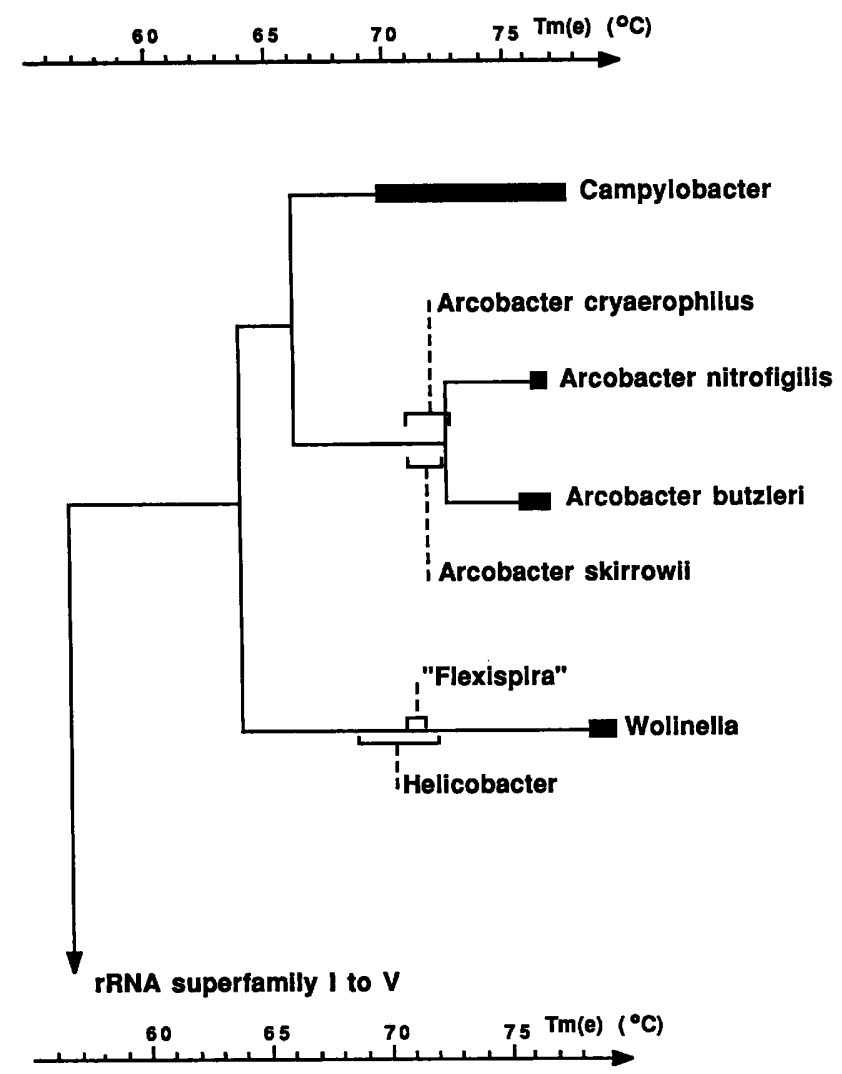

FIG. 5. Simplified rRNA cistron similarity dendrogram of rRNA superfamily VI. The solid bars indicate the $T_{m(e)}$ ranges observed within species or small groups. The dashed lines indicate rRNA branches for which no labeled rRNA is available yet.

$11.798,12.483,13.951$, and 14.503) are not given; therefore, the percentages for individual groups do not always total $100 \%$. The fatty acids with equivalent chain lengths of $13.815,15.485,15.853$, and 17.822 were identified as $14: 1$ cis 7, 14:0 3OH, 16:1 trans 9, and 18:1 cis 11, respectively, by using previously published data of Moss and Lambert-Fair (20). All of the arcobacters had 12:0, 14:0 3OH, 16:1 cis 9, 16:0, and 18:1 cis 11 as major components.

Phenotypic analysis. All of the strains which we studied were gram-negative, motile, curved rods. Alpha-hemolysis was common in $A$. skirrowii strains. With the exception of a few $A$. butzleri strains that were also alpha-hemolytic, all of the other strains were nonhemolytic. The colony color could be estimated best on the charcoal-based medium. The color of $A$. cryaerophilus colonies varied from beige to yellow. $A$. nitrofigilis colonies were white, $A$. butzleri colonies were whitish to beige, and $A$. skirrowii colonies were greyish. The results of the phenotypic tests are summarized in Table 4.

\section{DISCUSSION}

Difierentiation between Arcobacter species. In this study, the taxonomic relationships of 83 Arcobacter strains were determined by using a polyphasic approach that included DNA-rRNA hybridization experiments, DNA-DNA hybridization experiments, determinations of DNA base compositions, SDS-PAGE of whole-cell proteins, an analysis of fatty acid compositions, and a phenotypic analysis consisting of approximately 30 classical phenotypic tests.

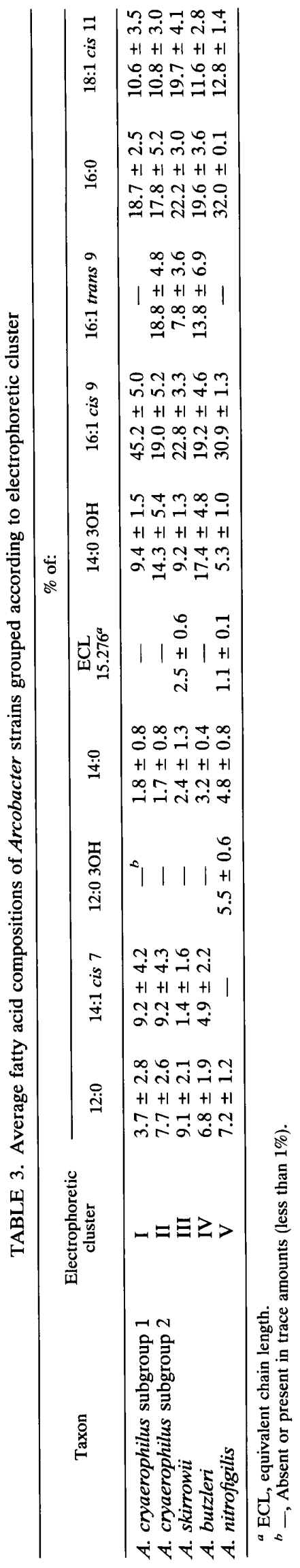




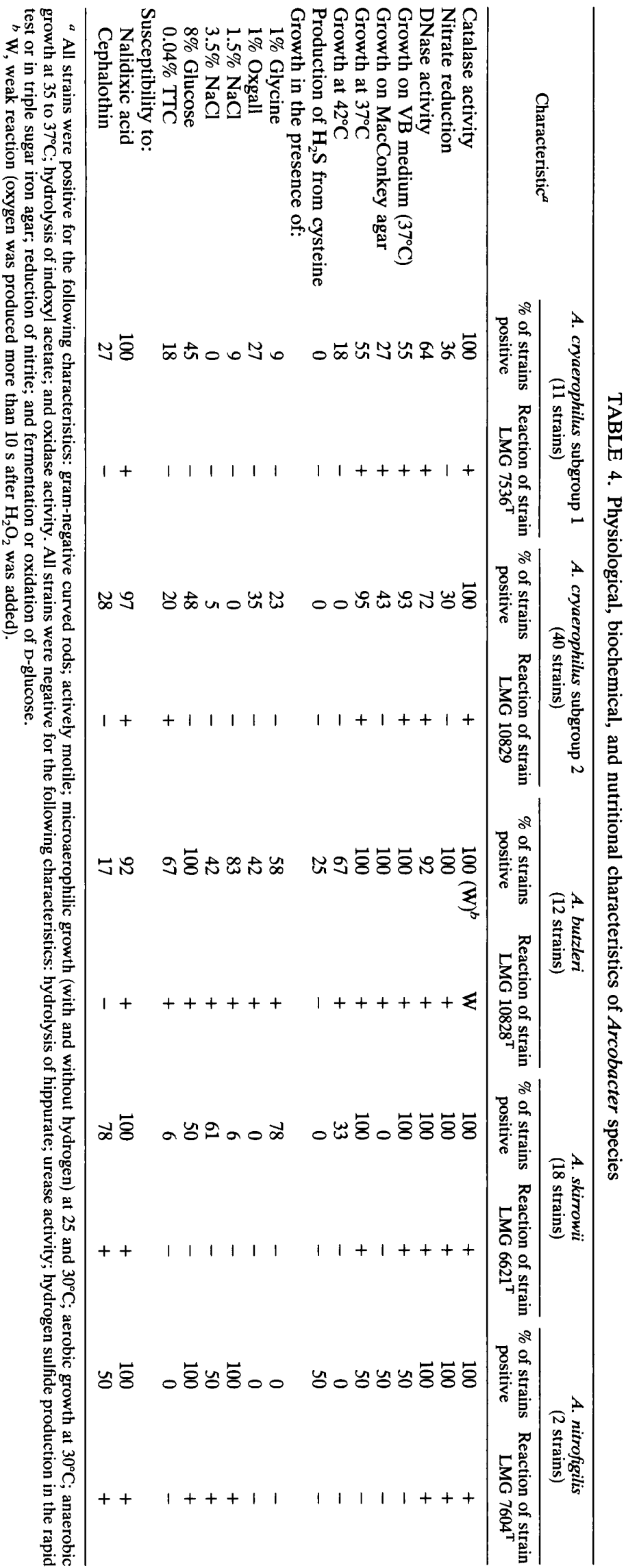


All of the strains were first grouped by using SDS-PAGE of whole-cell proteins. We identified four major electrophoretic clusters, which grouped with the reference strains of $A$. nitrofigilis (cluster V), $A$. cryaerophilus hybridization group 1A (cluster I) (12), A. cryaerophilus hybridization group 1B (cluster II) (12), and $A$. butzleri (cluster IV) (Fig. 1). A fifth cluster (cluster III) contained no reference strains. The results of DNA-DNA hybridization experiments showed that (i) despite their rather different protein profiles, all cluster I and II strains belong to $A$. cryaerophilus, (ii) all cluster IV strains belong to $A$. butzleri, and (iii) all cluster III strains belong to a new species, for which the name Arcobacter skirrowii is proposed below. Representative strains of all species were selected to determine their DNA base compositions. We did not observe significant differences between the Arcobacter species as all strains had $\mathrm{G}+\mathrm{C}$ contents between 27 and $30 \mathrm{~mol} \%$.

The phylogenetic affiliations of representative strains of all five electrophoretic clusters were determined by using DNArRNA hybridization experiments. From the results of previous studies it was clear that the genus Arcobacter is closely related to the genus Campylobacter (32), and therefore, both genera were placed in the family Campylobacteraceae (30). $A$. nitrofigilis was shown to constitute a separate rRNA branch within the Arcobacter rRNA homology group (Fig. 5) (32). In a previous study, we included three atypical $A$. cryaerophilus strains (32). Strain LMG 6620 (= CCUG 10373 ) occupied a separate position on the $T_{m(e)}$ dendrogram; in this study, this strain was identified as an $A$. butzleri strain (Fig. 1, 2, and 4). Other representatives of this species, including the type strain, had similar $T_{m(e)}$ values versus radioactively labeled Arcobacter rRNAs (Table 2) and thus occupied similar positions on the $T_{m(e)}$ dendrogram (Fig. 5). These DNA-rRNA hybridization results support and extend the DNA-DNA hybridization results of Kiehlbauch et al. (12). They indicate that the organism that was formerly called "C. butzleri" is indeed a true member of the genus Arcobacter; it is transferred to this genus, renamed $A$. butzleri comb. nov., and described below.

The two remaining $A$. cryaerophilus-like strains that were included in our previous study (strains LMG $6621^{\mathrm{T}}$ [= CCUG $10374^{\mathrm{T}}$ ] and LMG 8538 [= CCUG 10375]) (32) were identified in this study as $A$. skirrowii strains. The $A$. skirrowii strains had similar $T_{m(e)}$ values versus both Arcobacter rRNAs (Table 2 and Fig. 5). A. cryaerophilus subgroup 1 and 2 strains (electrophoretic clusters I and II, respectively) had similar $T_{m(e)}$ values versus rRNAs from $A$. nitrofigilis and $A$. butzleri (Table 2 and Fig. 5).

The fatty acid compositions of all Arcobacter strains were determined to evaluate the usefulness of this characteristic for differentiation and identification of Arcobacter taxa. The two electrophoretic subgroups of $A$. cryaerophilus could be differentiated easily from each other by the amounts of the two isomers of 16:1 (Table 3). A. cryaerophilus subgroup 1 strains (electrophoretic cluster I) had no 16:1 trans 9 and a very high percentage of $16: 1$ cis $9( \pm 45 \%)$, which allowed clear-cut differentiation from all other arcobacters. $A$. cryaerophilus subgroup 2 strains (electrophoretic cluster II) had equal amounts of both $16: 1$ isomers $( \pm 19 \%)$. The overall fatty acid compositions of the $A$. cryaerophilus subgroup 2 strains were very similar to those of the $A$. butzleri strains (Table 3). The A. skirrowii strains could be differentiated easily from most other taxa by the presence of an unknown fatty acid with an equivalent chain length of 15.276 and by a high percentage of $18: 1 \mathrm{cis} 11$. Additional differentiating fatty acids are shown in Table 3 . The $A$. nitrofigilis strains had an overall fatty acid profile that was very different from the profiles of the other arcobacters. Unexpectedly, one $A$. skirrowii strain (strain LMG 11073) had a fatty acid composition which corresponded to the composition of the $A$. butzleri and $A$. cryaerophilus subgroup 2 strains.

When the classical phenotypic tests were used, $A$. nitrofigilis could be differentiated from the other arcobacters by its nitrogenase activity (19) and by its typical colony morphology. A. nitrofigilis colonies are whitish and round, while the colonies of other arcobacters are beige to yellow and have a more irregular watery morphology. Furthermore, $A$. nitrofigilis could also be differentiated from $A$. cryaerophilus and $A$. skirrowii by its ability to grow in the presence of $1.5 \%$ $\mathrm{NaCl}$ and from $A$. butzleri by its strong catalase reaction. $A$. skirrowii colonies are greyish and alpha-hemolytic, a characteristic that occurs in only a few $A$. butzleri strains and is absent in all other arcobacters. A. skirrowii could be differentiated from $A$. cryaerophilus by its ability to grow in the presence of $1 \%$ glycine (14 of 18 strains versus 10 of 51 strains) and its susceptibility to cephalothin ( $30-\mu \mathrm{g}$ discs) (14 of 18 strains versus 14 of 51 strains). A. skirrowii differs from $A$. butzleri by its inability to grow on MacConkey agar and by the fact that most $A$. skirrowii strains do not grow in the presence of $1.5 \% \mathrm{NaCl}(1$ of 18 strains versus 10 of 12 strains) and are susceptible to cephalothin (30- $\mu \mathrm{g}$ discs) (14 of 18 strains versus 2 of 12 strains). A. butzleri differs from $A$. cryaerophilus by its ability to grow in the presence of $1.5 \% \mathrm{NaCl}$ (10 of 12 strains versus 1 of 51 strains) and from all other arcobacters by its weak catalase activity. A total of $68 \%$ of all $A$. cryaerophilus strains do not reduce nitrate, in contrast with all other arcobacters. Additional characteristics that are helpful for differentiating Arcobacter species by means of classical phenotypic tests are shown in Table 4. A number of discrepancies between our results and those of Kiehlbauch et al. (12) were found. In general, we found higher percentages of growth for $A$. cryaerophilus strains than Kiehlbauch et al. found (e.g., growth in the presence of $1 \%$ glycine, growth in the presence of $0.04 \%$ TTC, growth at $42^{\circ} \mathrm{C}$ ). This might be explained by the higher number of strains investigated in our study ( $51 \mathrm{~A}$. cryaerophilus strains versus 14 strains). Surprisingly, only 16 of $51 \mathrm{~A}$. cryaerophilus strains reduced nitrate to nitrite.

We found that differentiating among Arcobacter species by using classical phenotypic tests is rather difficult. Using phenotypic criteria might give erroneous results because of a shortage of clear-cut differentiating tests, a phenomenon which has also been observed in the closely related genus Campylobacter (30).

Descriptions of new taxa. Within $A$. cryaerophilus, we identified two subgroups of strains. We believe that our subgroups correspond to the two subgroups of Kiehlbauch et al. (12). Indeed, six $A$. cryaerophilus strains were included in both studies; four of our subgroup 1 strains (strains LMG 6622, LMG 7536 ${ }^{\mathrm{T}}$, LMG 9065, and LMG 9066) belonged to the first genotypic and phenotypic subgroup of Kiehlbauch et al. (12), and two of our subgroup 2 strains (strains LMG 9909, and LMG 10829) belonged to the second genotypic and phenotypic subgroup of these authors. Strain LMG 10829 is the reference strain of Kiehlbauch et al. (12). The two subgroups could not be differentiated in the DNA-DNA and DNA-rRNA hybridization studies. Subgroup 1 strains (electrophoretic cluster I) and subgroup 2 strains (electrophoretic cluster II) have similar DNA base compositions, occupy similar positions on the $T_{m(e)}$ dendrogram, and exhibit 46 to $69 \%$ DNA binding, while within the subgroups DNA binding values of 56 to $100 \%$ were found. The two subgroups differ in 
their protein profiles (Fig. 1 and 2), their fatty acids compositions (Table 3), and their DNA restriction fragment length patterns (13). Therefore, although these two subgroups may deserve separate taxonomic status, we do not propose subspecies or infrasubspecific names because so far there are no descriptive phenotypic features to differentiate the two subgroups. The reference strain of Kiehlbauch et al. (12), strain LMG 10829 (= CDC D2610 = ATCC 49615), was also a typical representative of its group in the SDS-PAGE study and in the fatty acid analysis. The description of $A$. cryaerophilus is the description of $C$. cryaerophila given by Kiehlbauch et al. (12), with the alterations described below. All strains produce catalase. Growth occurs at 35 to $37^{\circ} \mathrm{C}$ under anaerobic conditions. Variable growth occurs at 37 and $42^{\circ} \mathrm{C}$ under microaerobic conditions. Variable growth occurs on MacConkey agar and on VB medium. Poor growth occurs in the presence of $1 \%$ glycine. Reduction of nitrates is variable. Growth in the presence of $1 \%$ oxgall is variable.

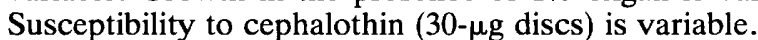

Emended description of the genus Arcobacter. Arcobacter (Ar'co.bac.ter.L.n.arcus, bow; Gr.n.bacter, rod; M. L. masc. n. Arcobacter, bow-shaped rod) cells are gram-negative nonsporeforming rods $(0.2$ to $0.9 \mu \mathrm{m}$ wide and 1 to $3 \mu \mathrm{m}$ long) that are usually curved, S-shaped, or helical. Motile with a darting, corkscrewlike movement by means of a single polar, unsheathed flagellum. Growth occurs at 15, 25, and $30^{\circ} \mathrm{C}$; variable growth occurs at 37 and $42^{\circ} \mathrm{C}$. Optimal growth occurs under microaerobic conditions $\left(3\right.$ to $\left.10 \% \mathrm{O}_{2}\right)$. There is no hydrogen requirement for microaerobic growth. Aerobic growth occurs at $30^{\circ} \mathrm{C}$. Anaerobic growth occurs at 35 to $37^{\circ} \mathrm{C}$. Carbohydrates are neither fermented nor oxidized. Organic acids and amino acids are utilized as carbon sources. Growth occurs in the presence of $1 \%$ (wt/vol) pteridine vibriostatic compound $0 / 129$. Growth is inhibited in the presence of $0.1 \%$ TTC. A TTC concentration of $0.04 \%$ is inhibitory to some strains. Reduction of nitrate, hydrolysis of DNA, and growth in the presence of $1 \%$ glycine, $1 \%$ oxgall, 1.5 and $3.5 \% \mathrm{NaCl}$, and $8 \%$ glucose are variable. The strains have oxidase and catalase activities. Negative reactions in methyl red and Voges-Proskauer tests, no reduction of nitrite, no urease activity, no hydrolysis of hippurate, and no production of indole. No production of hydrogen sulfide from triple sugar iron agar or in the rapid $\mathrm{H}_{2} \mathrm{~S}$ test; variable production of hydrogen sulfide from cysteine. Esculin and starch are not hydrolyzed, and gelatin is not liquified. Most strains are nonhemolytic; alpha-hemolysis is often observed with $A$. skirrowii strains. Nearly all strains are susceptible to nalidixic acid; susceptibility to cephalothin $(30-\mu \mathrm{g}$ discs $)$ is variable. For all species examined so far, menaquinone 6 and a second atypical menaquinone 6 , the identity of which remains to be established, are the major respiratory quinones. All strains have 12:0, 14:0 3OH, 16:1 cis 9, 16:0, and 18:1 cis 11 as major fatty acids.

Strains have been isolated from root-associated sediments and roots of salt marsh plants, from aborted fetuses of several species of farm animals, and from various other animal and human sources. The pathogenicity of these organisms is unknown.

The type species is Arcobacter nitrofigilis. The DNA base composition ranges from 27 to $30 \mathrm{~mol} \%$.

Description of Arcobacter skirrowii sp. nov. Arcobacter skirrowii (ski.ro'wi.i.) N. L. gen. n. skirrowii, of Skirrow, in honor of M. B. Skirrow, a British microbiologist who was the first to describe a simple isolation technique for Campylobacter jejuni obtained from stool specimens, which enabled most routine laboratories to culture the organisms.
Cells are 1 to $3 \mu \mathrm{m}$ long and 0.2 to $0.4 \mu \mathrm{m}$ wide. After 3 days of incubation on blood agar, colonies are 2 to $3 \mathrm{~mm}$ in diameter and greyish and have a flat irregular shape on moist media. Most characteristics are as given above for the genus. Additional characteristics are given below. Most strains produce alpha-hemolysis on blood agar. Growth occurs on VB medium; no growth occurs on MacConkey agar. No growth occurs in the presence of $1 \%$ oxgall. No production of hydrogen sulfide from cysteine. Most strains (14 of 18 strains tested) grow in the presence of $1 \%$ glycine. Most strains (17 of 18 strains tested) do not grow in the presence of $0.04 \% \mathrm{TTC}$ and $1.5 \% \mathrm{NaCl}$. All strains are susceptible to nalidixic acid ( $30-\mu \mathrm{g}$ discs), and most strains (14 of 18 strains tested) are susceptible to cephalothin (30- $\mu \mathrm{g}$ discs).

The DNA base composition of $A$. skirrowii is 29 to 30 mol\%. The major fatty acids are 12:0, 14:0 3OH, 16:1 cis 9, 16:1 trans $9,16: 0$, and 18:1 cis 11 . Additional fatty acids that are present in smaller quantities are 14:1 cis 7, 14:0, and an unidentified fatty acid with an equivalent chain length of 15.276.

So far, $A$. skirrowii strains have been isolated mainly from preputial fluids of bulls; the other strains are bovine, porcine, and ovine isolates obtained from aborted fetuses and diarrheic feces. The clinical significance of this new species remains to be established.

The type strain is strain LMG 6621 (= Skirrow 449/80 = CCUG 10374), which was isolated from the feces of a lamb with diarrhea. Characteristics of the type strain are summarized in Table 4. Its $\mathrm{G}+\mathrm{C}$ content is $29 \mathrm{~mol} \%$. All of our $A$. skirrowii strains have been deposited in the Culture Collection of the Laboratorium voor Microbiologie, University of Ghent, Ghent, Belgium.

Description of Arcobacter butzleri comb. nov. Arcobacter butzleri cells are 0.2 to $0.4 \mu \mathrm{m}$ wide and 1 to $3 \mu \mathrm{m}$ long. After 3 days of incubation on blood agar plates, colonies are 2 to 4 $\mathrm{mm}$ in diameter and predominantly round, and most are whitish. Most characteristics are as given above for the genus. Additional characteristics are described below. Weak catalase activity. All strains grow on VB medium and MacConkey agar and reduce nitrate. Growth occurs in the presence of $8 \%$ glucose. Most strains (11 of 12 strains tested) produce DNase, and most strains (10 of 12 strains tested) grow in the presence of $1.5 \% \mathrm{NaCl}$. Growth at $42^{\circ} \mathrm{C}$ is variable ( 8 of the 12 strains tested grow), and hydrogen sulfide production from cysteine is variable ( 3 of the 12 strains tested produce $\mathrm{H}_{2} \mathrm{~S}$ ). The following characteristics are variable: growth in the presence of $1 \%$ oxgall ( 5 of the 12 strains tested are positive), growth in the presence of $3.5 \%$ $\mathrm{NaCl}$ ( 5 of the 12 strains tested are positive), growth in the presence of $1 \%$ glycine ( 7 of the 12 strains tested are positive), and growth in the presence of $0.04 \%$ TTC ( 8 of the 12 strains tested are positive). Most strains (11 of 12 strains tested) are susceptible to nalidixic acid, and most strains (10 of 12 strains tested) are resistant to cephalothin $(30-\mu \mathrm{g}$ discs).

The DNA base composition varies between 28 and 29 mol\%. The major fatty acids are 12:0, 14:0 30H, 16:1 cis 9, 16:1 trans $9,16: 0$, and 18:1 cis 11 . Additional fatty acids that are present in smaller quantities are 14:1 cis 7 and 14:0.

Most $A$. butzleri strains have been isolated from diarrheic feces of humans and animals, from aborted fetuses, and from human blood. Although the association with diarrheal illness in humans and animals is striking, the clinical significance of A. butzleri remains to be proven. 
The type strain is strain LMG 10828 (= CDC D2686 = ATCC 49616), which was isolated from human feces. Characteristics of the type strain are shown in Table 4.

\section{ACKNOWLEDGMENTS}

P.V. is indebted to the National Fund for Scientific Research (Belgium) for a position as a senior research assistant. K.K. is indebted to the Fund for Medical Scientific Research, Belgium, for research and personnel grants. Part of this research was carried out in the framework of contract BAP-0138-B with the Biotechnological Action Program of the Commission of the European Community.

We thank all depositors of strains listed in Table 1. We thank A. Von Graevenitz, Department of Medical Microbiology, University of Zurich, Zurich, Switzerland, and T. O. MacAdoo, Department of Foreign Languages, Virginia Polytechnic Institute and State University, Blacksburg, for their help in naming the new Arcobacter species.

\section{REFERENCES}

1. Barrett, T. J., C. M. Patton, and G. K. Morris. 1988. Differentiation of Campylobacter species using phenotypic characterization. Lab. Med. 19:96-102.

2. De Ley, J. 1970. Reexamination of the association between melting point, buoyant density, and chemical base composition of deoxyribonucleic acid. J. Bacteriol. 101:738-754.

3. De Ley, J., H. Cattoir, and A. Reynaerts. 1970. The quantitative measurement of DNA hybridization from renaturation rates. Eur. J. Biochem. 12:133-142.

4. De Ley, J., and J. De Smedt. 1975. Improvements on the membrane filter method for DNA:rRNA hybridization. Antonie van Leeuwenhoek J. Microbiol. Serol. 41:287-307.

5. Ellis, W. A., S. D. Neill, J. J. O'Brien, H. W. Ferguson, and J. Hanna. 1977. Isolation of Spirillum/Vibrio-like organisms from bovine fetuses. Vet. Rec. 100:451-452.

6. Ellis, W. A., S. D. Neill, J. J. O'Brien, and J. Hanna. 1978. Isolation of Spirillum-'ike organisms from pig fetuses. Vet. Rec. 102:106.

7. Gill, K. P. W. 1983. Aerotolerant Campylobacter strain isolated from a bovine preputial sheath washing. Vet. Rec. 112:459.

8. Goossens, H., M. De Boeck, H. Cogniau, L. Vlaes, C. Van den Borre, and J.-P. Butzler. 1986. Modified selective medium for the isolation of Campylobacter spp. from feces: comparison with Preston medium, a blood-free medium, and a filtration system. J. Clin. Microbiol. 24:840-843.

9. Goossens, H., B. Pot, L. Vlaes, C. Van den Borre, R. Van den Abbeele, C. Van Naelten, J. Levy, H. Cogniau, P. Marbehant, J. Verhoef, K. Kersters, J.-P. Butzler, and P. Vandamme. 1990. Characterization and description of "Campylobacter upsaliensis" isolated from human feces. J. Clin. Microbiol. 28:1039 1046.

10. Higgins, R., and R. Degre. 1979. Isolation of Spirillum-like organisms from pig and bovine fetuses. Vet. Rec. 104:262-263.

11. Higgins, R., and R. Degre. 1979. Spirillum-like organism isolated from pig and bovine fetuses. Vet. Rec. 104:559.

12. Kiehlbauch, J. A., D. J. Brenner, M. A. Nicholson, C. N. Baker, C. M. Patton, A. G. Steigerwalt, and I. K. Wachsmuth. 1991. Campylobacter butzleri sp. nov. isolated from humans and animals with diarrheal illness. J. Clin. Microbiol. 29:376-385.

13. Kiehlbauch, J. A., B. D. Plikaytis, B. Swaminathan, D. N. Cameron, and I. K. Wachsmuth. 1991. Restriction fragment length polymorphisms in the ribosomal genes for species identification and subtyping of aerotolerant Campylobacter species. J. Clin. Microbiol. 29:1670-1676.

14. Korn-Wendisch, F., A. Kempf, E. Grund, R. M. Kroppenstedt, and H. J. Kutzner. 1989. Transfer of Faenia rectivingula Kurup and Agre 1983 to the genus Saccharopolyspora Lacey and Goodfellow 1975, elevation of Saccharopolyspora hirsuta subsp. taberi Labeda 1987 to species level, and emended description of the genus Saccharopolyspora. Int. J. Syst. Bacteriol. 39:430-441.

15. Laemmli, U. K. 1970. Cleavage of structural proteins during the assembly of the head of bacteriophage T4. Nature (London) 227:680-685.

16. Lambert, M. A., C. M. Patton, T. J. Barrett, and C. W. Moss. 1987. Differentiation of Campylobacter and Campylobacter-like organisms by cellular fatty acid composition. J. Clin. Microbiol. 25:706-713.

17. Logan, E. F., S. D. Neill, and D. P. Mackie. 1982. Mastitis in dairy cows associated with an aerotolerant Campylobacter. Vet. Rec. 110:229-230.

18. Marmur, J., and P. Doty. 1962. Determination of the base composition of deoxyribonucleic acid from its thermal denaturation temperature. J. Mol. Biol. 5:109-118.

19. McClung, C. R., D. G. Patriquin, and R. E. Davis. 1983 Campylobacter nitrofigilis sp. nov., a nitrogen-fixing bacterium associated with roots of Spartina alterniflora Loisel. Int. J. Syst. Bacteriol. 33:605-612.

20. Moss, C. W., and M. A. Lambert-Fair. 1989. Location of double bonds in monounsaturated fatty acids of Campylobacter cryaerophila with dimethyl disulfide derivatives and combined gas chromatography-mass spectrometry. J. Clin. Microbiol. 27:1467-1470.

21. Neill, S. D., J. N. Campbell, J. J. O'Brien, S. T. C. Weatherup, and W. A. Ellis. 1985. Taxonomic position of Campylobacter cryaerophila sp. nov. Int. J. Syst. Bacteriol. 35:342-356.

22. Neill, S. D., W. A. Ellis, and J. J. O'Brien. 1978. The biochemical characteristics of Campylobacter-like organisms from cattle and pigs. Res. Vet. Sci. 25:368-372.

23. Neill, S. D., W. A. Ellis, and J. J. O'Brien. 1979. Designation of aerotolerant Campylobacter-like organisms from porcine and bovine abortions to the genus Campylobacter. Res. Vet. Sci. 27:180-186.

24. Neill, S. D., J. J. O'Brien, and W. A. Ellis. 1980. The isolation of aerotolerant Campylobacter. Vet. Rec. 106:152-153.

25. Pot, B., M. Gillis, B. Hoste, A. Van De Velde, F. Bekaert, K. Kersters, and J. De Ley. 1989. Intra- and intergeneric relationships of the genus Oceanospirillum. Int. J. Syst. Bacteriol. 39:23-34.

26. Sokal, R. R., and P. H. A. Sneath. 1963. Principles of numerical taxonomy. W. H. Freeman and Co., San Francisco.

27. Stead, D. E. 1989. Grouping of Xanthomonas campestris pathovars of cereals and grasses by fatty acid profiling. Bull. OEPP (Organ. Eur. Mediterr. Prot. Plant.)/EPPO (Eur. Mediterr. Plant Prot. Organ.) Bull. 19:57-68.

28. Tee, W., R. Baird, M. Dyall-Smith, and B. Dwyer. 1988. Campylobacter cryaerophila isolated from a human. J. Clin. Microbiol. 26:2469-2473.

29. Thompson, L. M., III, R. M. Smibert, J. L. Johnson, and N. R. Krieg. 1988. Phylogenetic study of the genus Campylobacter. Int. J. Syst. Bacteriol. 38:190-200.

30. Vandamme, P., and J. De Ley. 1991. Proposal for a new family, Campylobacteraceae. Int. J. Syst. Bacteriol. 41:451-455.

31. Vandamme, P., E. Falsen, B. Pot, B. Hoste, K. Kersters, and J. De Ley. 1989. Identification of EF group 22 campylobacters from gastroenteritis cases as Campylobacter concisus. J. Clin. Microbiol. 27:1775-1781.

32. Vandamme, P., E. Falsen, R. Rossau, B. Hoste, P. Segers, R. Tytgat, and J. De Ley. 1991. Revision of Campylobacter, Helicobacter, and Wolinella taxonomy: emendation of generic descriptions and proposal of Arcobacter gen. nov. Int. J. Syst. Bacteriol. 41:88-103.

33. Vandamme, P., and S. Lauwers. Unpublished data.

34. Vandamme, P., B. Pot, E. Falsen, K. Kersters, and J. De Ley. 1990. Intra- and interspecific relationships of veterinary campylobacters revealed by numerical analysis of electrophoretic protein profiles and DNA:DNA hybridizations. Syst. Appl. Microbiol. 13:295-303.

35. Vandamme, P., B. Pot, and K. Kersters. 1991. Differentiation of campylobacters and Campylobacter-like organisms by numerical analysis of one-dimensional electrophoretic protein patterns. Syst. Appl. Microbiol. 14:57-66.

36. Vauterin, L., J. Swings, and K. Kersters. 1991. Grouping of Xanthomonas campestris pathovars by SDS-PAGE of proteins. J. Gen. Microbiol. 137:1677-1687. 